\title{
Effect of Cadmium and Lead on Total Hemocyte Count of Achroia grisella Fabr. (Lepidoptera: Pyralidae)
}

\author{
Kadmiyum ve Kurşunun Achroia grisella Fabr. (Lepidoptera: Pyralidae)'nın Toplam \\ Hemosit Sayısina Etkisi
}

\author{
Nevran Eylem AKMAN GÜNDÜZ ${ }^{* 1, a}$, Sevcan MERCAN ${ }^{2, b}$, Özgür ÖZCAN ${ }^{3, c}$ \\ ${ }^{1}$ Science and Art Faculty, Department of Biology, Ondokuz Mayls University, 55139, Samsun, Türkiye \\ ${ }^{2}$ Vocational School of Health Services, Ondokuz Mayls University, 55139, Samsun, Türkiye \\ ${ }^{3}$ Samsun Metropolitan Municipality Water and Sewerage Administration, Samsun, Türkiye
}

• Geliş tarihi / Received: 22.02.2019 • • Düzeltilerek geliş tarihi / Received in revised form: 24.10.2019 • Kabul tarihi / Accepted: 11.11 .2019

\begin{abstract}
The effect of cadmium $(\mathrm{Cd})$ and lead $(\mathrm{Pb})$ on total hemocyte count $(\mathrm{THC})$ of Achroia grisella was examined under laboratory conditions. Larvae were reared on an artificial diet medium contaminated with three different concentrations $(50,100$ and $200 \mathrm{mg} / \mathrm{kg}$ ) of $\mathrm{Cd}$ and $\mathrm{Pb}$. In the control group the insects fed a heavy metal free diet. All of the insects were kept at $25 \pm 2{ }^{\circ} \mathrm{C}$ temperature, $60 \pm 5 \%$ relative humidity and $16 \mathrm{~L}: 8 \mathrm{D}$ photoperiod conditions. The obtained data showed that the total hemocyte count of larvae exposed to $\mathrm{Cd}$ resulted in a significant decrease at all concentrations, whereas total hemocyte count of $\mathrm{Pb}$-treated groups decreased only at the highest concentrations of $\mathrm{Pb}$.
\end{abstract}

Keywords: Achroia Grisella, Hemolymph, Total Hemocyte Count

$\ddot{O} z$

Kadmiyum (Cd) ve kurş̧nun (Pb) Achroia grisella'nın toplam hemosit saylst üzerindeki etkisi laboratuar koşullarında araştırllmuştır. Larvalar üç farklı konsantrasyonda $(50,100 \mathrm{ve} 200 \mathrm{mg} / \mathrm{kg}$ ) Cd ve Pb ile kontamine olmuş yapay besin ortamında yetiștirilmiștir. Kontrol grubunda böcekler ağır metal içermeyen besin ile beslenmiștir. Tüm böcekler $25 \pm 2$ ${ }^{\circ} \mathrm{C}$ sicaklık, $60 \pm 5 \%$ bağıl nem (RH) ve 16A:8K fotoperiyot koşullarında tutulmuştur. Elde edilen bulgular kadmiyuma maruz kalan larvaların toplam hemosit saylsinın tüm konsantrasyonlarda azaldığını, kurşuna maruz kalanlarda ise toplam hemosit sayısının sadece en yüksek konsantrasyonda azaldiğını göstermiştir.

Anahtar kelimeler: Achroia Grisella, Hemolenf, Toplam Hemosit Saylsı

*a Nevran Eylem AKMAN GÜNDÜZ; gunduzeylem@gmail.com, Tel: (0362) 31219 19, orcid.org/0000-0001-5777-470X

${ }^{\mathrm{b}}$ orcid.org/0000-0003-0140-6777 ${ }^{\mathrm{c}}$ orcid.org/0000-0003-0661-2350 


\section{Introduction}

Heavy metal pollution in air and water has been associated with various negative effects on insects (Borowska et al., 2004; El-Sheikh et al., 2010; Suganya et al., 2016). Borowska et al. (2004) showed that rearing Musca domestica (Diptera: Muscidae) larvae on an artificial media contaminated with copper $(\mathrm{Cu})$, zinc $(\mathrm{Zn})$, lead $(\mathrm{Pb})$ and cadmium $(\mathrm{Cd})$ resulted in their accumulation in the body and this accumulation disturbed the larval development and the survival rate of larvae and pupae. Suganya et al. (2016) studied the toxicity and antioxidant enzymes activity of Spodoptera litura (Lepidoptera: Noctuidae) larvae against heavy metal application. They observed that $\mathrm{Cd}$ and $\mathrm{Pb}$ metals are toxic on S. litura larvae and cause strong oxidative stres. In another study El-Sheikh et al. (2010) proved that the larval mortality percent of Culex pipiens $\mathrm{L}$. (Diptera: Culicidae) larvae increased as the concentration of heavy metals namely; $\mathrm{Cd}, \mathrm{Cu}, \mathrm{Pb}$ and mercury $(\mathrm{Hg})$ increased. In addition, Bischof (1995) reported that different types of metals significantly affects the biochemical composition of parasitized Lymantria dispar (Lepidoptera: Lymantriidae) larvae.

Insect hemocytes are similar to vertebrate leukocytes and the efficiency of the immune system in insects is correlated with the number of hemocytes and their function (Berger and Slavičková, 2008; Borowska and Pyza, 2011). Their primary functions are coagulation, phagocytosis, encapsulation, detoxification, and storage and distribution of nutritive materials (Sanjayan et al., 1996; Eslin and Prévost, 1998; Siddiqui and Al-Khalifa, 2014). Previous studies showed that heavy metals and insecticides have a clear effect on hemocyte profile of insects (Borowska and Pyza, 2011, Kurt and Kayış, 2015).

Achroia grisella (L.) (Lepidoptera: Pyralidae) is a ubiquitous pest species of honey bee colonies globally. Larval stages of this moth species feed on wax, polen and honey, thereby they cause heavy economic damage in apiculture industry. Due to this reason, many researchers have focused on its biology, behaviour and control. A. grisella is also used as a model organism and system for insect physiology, genomic and proteomic investigations (Ellis et al., 2013; Mahgoup et al., 2015; Gleason et al., 2016; Çelik et al., 2017). The aim of this study was to determine the effect of $\mathrm{Cd}$ and $\mathrm{Pb}$ on total hemocyte number of A. grisella.

\section{Material and Method}

A laboratory stock culture of A. grisella has been maintained for several years on an artificial diet of honeycomb (200 g), bran (860 g), glycerol (300 $\mathrm{ml})$, honey $(150 \mathrm{ml})$ and distilled water $(150 \mathrm{ml})$ at the Animal Physiology Research Laboratory, Ondokuz Mayıs university.

The effect of heavy metals on Total Hemocyte Count (THC) of A. grisella was tested through diet incorporation assay. A. grisella larvae were fed on an artificial diet contaminated with three different concentrations $(50,100$ and $200 \mathrm{mg} / \mathrm{kg}$ ) of $\mathrm{Cd}$ or $\mathrm{Pb}$ throughout all larval stages. In the control group the insects fed a heavy metal free diet. All of the insects were kept at $25 \pm 2{ }^{\circ} \mathrm{C}$ temperature, $60 \pm 5 \%$ relative humidity $(\mathrm{RH})$ and 16L:8D photoperiod conditions. For analysis of THC of A. grisella, last instar larvae were pierced on the first hind leg with a sterile needle. Five $\mu \mathrm{L}$ of hemolymph was spread on a glass slide and allowed to air dry for 20-30 minutes to facilitate the adhesion of hemocytes to the glass. Cells were fixed in methanol:acetic acid (3:1) for 10 minutes. The slides were stained with Giemsa for 10 minutes and they were rapidly washed with distilled water. After air drying the slides were treated with xylene and then mounted in Entellan. THC were assayed under a Zeiss Primo Star microscobe. Ten larvae were evaluated for each experimental and control group. Direct microscobic somatic cell counting (DMSCC) method was used to determine THC of A. grisella larvae (Fitts and Laird, 2004; Kul, 2013). Twenty randomly selected area was used to count hemocytes for each slide. THC were obtained by multiplying the mean cell numbers by the microscope factor obtained by calculating the microscope sight field. Data in graphs were represented as mean \pm standard error of the mean values. Statistical differences between the treated and control groups were determined by nonparametric Kruskal-Wallis H-test followed by Mann-Whitney U-test using SPSS 21.0. Differences were consider significant at $p \leq 0.05$.

\section{Results}

The effect of cadmium (Cd) on THC of A. grisella is presented in Figure 1. The results showed that treatment with $\mathrm{Cd}$ influenced the THC of $A$. grisella. The mean number of THC of Cd-treated larvae declined significantly at all tested concentrations compared to control $(p \leq 0.05)$ (Figure 1). However, THC did not indicate a 
considerable change among different concentrations $(p>0.05)$.

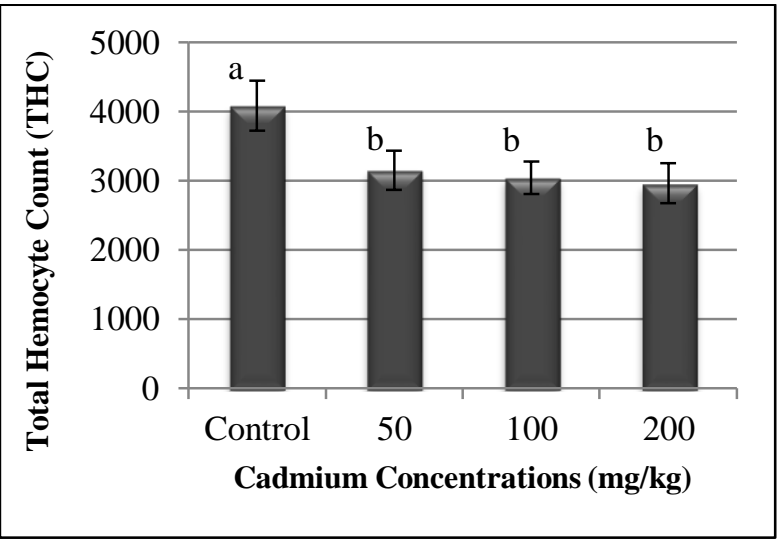

Figure 1. Effect of different concentrations of cadmium (Cd) on total hemocytes count of $A$. grisella. Different letters denote significant differences $(p \leq 0.05)$.

Our results showed that THC of the lead $(\mathrm{Pb})$ treated groups also showed a tendency to decrease compared with the control (Figure 2). This decrease was only significant at $200 \mathrm{mg} / \mathrm{kg}$ compared to the control $(p \leq 0.05)$.

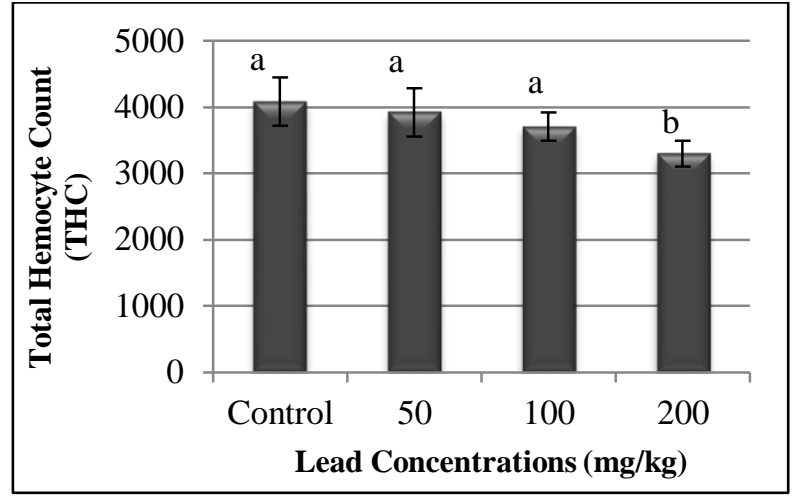

Figure 2. Effect of different concentrations of lead $(\mathrm{Pb})$ on total hemocytes count of $A$. grisella. Different letters denote significant differences $(p$ $\leq 0.05$ ).

\section{Discussion}

Invertebrates are good models to study toxicity of heavy metals and are useful bioindicators of contamination of the environment (Borowska and Pyza, 2011). Previous studies showed that toxicity of heavy metals on immune cells are related to the species, dose, the method of application, developmental stage of animals and animal's sensitivity (Kazimírová and Slovák, 1996; ElSheikh et al., 2010; Suganya et al., 2016). Here, we tested the heavy metal toxicity at cellular levels and examined the lesser wax moth's hemocytes as an element of its immune system.

Our results showed that THC of A. grisella larvae significantly decreased at all treated $\mathrm{Cd}$ concentrations. The mean $\mathrm{THC}$ of $\mathrm{Pb}$ - treated groups also decreased but the differences were significant at only $\mathrm{Pb} 200 \mathrm{mg} / 1000 \mathrm{mg}$ diet, as compared to control. These results are in agreement with those obtained by Borowska et al. (2004) where they reported that total number of circulating hemocytes and their adhesion ability significantly decreased with heavy metal application in $M$. domestica. These changes, interestingly, are similar to those produced by some of the insecticides and botanicals. For example, Sharma et al. (2003) observed a dosedependent reduction in THC in the last instar larvae of $S$. litura after $48 \mathrm{~h}$ of oral treatment of Neem gold. Likely, Kurt and Kayış (2015) proved that deltamethrin treatment caused a decrease in the THC of Galleria mellonella (Lepidoptera: Pyralidae) larvae at 24, 48 and $72 \mathrm{~h}$. In contrast to our results, Çelik et al. (2017) found that indole-3acetic acid application increased the THC in $A$. grisella larvae at all tested doses (2-1000 ppm). Likewise, Altuntaş et al. (2012) determined that gibberellic acid increased the THC in $G$. mellonella larvae.

There are some reports dealing with effects of heavy metals on endocrine system in insects. Endocrine system regulates the hemocyte populations and differentiations in insects (Prasada Rao et al., 1984; Ahmad and Khan, 1988; Sezer and Özalp, 2015). For instance, Sendi and Salehi (2010) showed that treatment with juvenile hormon analogue methoprene significantly decreased the THC in Papilio domeleus (Lepidoptera: Papilionidae). Similarly, Ahmad (1995) revealed that B-beta ecdysone and makisterone A (a phytoecdysone) treatment caused a decrease in THC of fifth instar nymphs of Dysdercus cingulatus (Hemiptera: Pyrrhocoridae). In addition, İzzetoglu and Karaçalı (2003) noted a significant adverse influence of 20- hydroxydysone on hemocytes of G. mellonella in vitro conditions. Sezer and Özalp (2015) also observed that pyriproxyfen treatment caused reduction in total hemocyte count of $G$. mellonella. Banakou and Dailianis (2010) reported that lipid peroxidation and DNA damage in Cd-treated hemocytes of molluscs ultimately contribute to cell death. These previous studies may help us to explain, at least, in part, the reason for decreasing hemocytes numbers in hemolymph of A. grisella with heavy metal application. 
However, to complete our knowledge about heavy metals on the immune system of A. grisella more detailed studies are required.

This study was presented as a poster presentation at Ecology 2018 International Symposium held in Kastamonu and the abstract was published in the congress book.

\section{Kaynaklar}

Ahmad, A. and Khan, M.A., 1988. Effects of triol and makisterone A on the hemocytes of Hieroglymphus nigrorepletus Boliver (Orthoptera: Acrididae), Proceedings of the Indian Academy of Sciences (Animal Sciences), 97(3), 203-210.

Ahmad, A., 1995. Changes in hemocyte counts following topical application of $\beta$-ecdysone and makisterone A on 5th instar nymphs of Dysdercus cingulatus Fabr. (Hemiptera: Pyrrhocoridae). Entomologia Croatica, 1, 41-48.

Altuntaş, H., Kılıç, A.Y., Uçkan, F. and Ergin, E., 2012. Effects of gibberellic acid on hemocytes of Galleria mellonella L. (Lepidoptera: Pyralidae). Environmental Entomology, 41(3), 688-696.

Banakou, E. and Dailianis, S., 2010. Involvement of $\mathrm{Na}+/ \mathrm{H}+$ exchanger and respiratory burst enzymes NDPH oxidase and NO synthase, in Cd-induced lipid peroxidation and DNA damage in haemocytes of mussels. Comparative Biochemistry and Physiology - Part C, 152, 346-352.

Berger, J. and Slavičková, K., 2008. Morphological characterization of hemocytes in the adult linden bug, Pyrrhocoris apterus (L.) (Heteroptera). Zoological Studies, 47(4), 466472.

Bischof, C., 1995. Effects of heavy metal stress on carbohydrate and lipid concentrations in the haemolymph and total body tissue of parasitized Lymantria dispar L. larv; (Lepidoptera). Comparative Biochemistry and Physiolology Part C, 112(1), 87-92.

Borowska, J., Sulima, B., Niklińska, M. and Pyza E., 2004. Heavy metal accumulation and its effects on development, survival and immunocompetent cells of the house fly Musca domestica from closed laboratory populations as model organism. Fresenius Environmental Bulletin, 13, 1402-1409.

Borowska, J. and Pyza, E., 2011. Effects of heavy metals on insect immunocompetent cells. Journal of Insect Physiology, 57, 760-770.
Çelik, D., Özbek, R., Uçkan, F., 2017. Effects of indole-3-acetic acid on hemocytes of Achoria grisella Fabr. (Lepidoptera: Pyralidae). Journal of Entomological Research Society, 19(2), 8393.

Ellis, J.D., Graham, J.R. and Mortensen, A., 2013. Standard methods for wax moth research. Journal of Apicultural Research, 52(1), 1-17.

El-Sheikh, T.M.Y., Fouda, M.A., Hassan, M.I., AbdElhamed, A. Abd-Elghaphar and Hasaballah, A.I., 2010. Toxicological effects of some heavy metal ions on Culex pipiens L. (Diptera: Culicidae). Egyptian Academic Journal of Biological Sciences, 2(1), 63-76.

Eslin, P. and Prévost, G., 1998. Hemocyte load and immune resistance to Asobora tabida are correlated in species of the Drosophila melanogaster subgroup. Journal of Insect Physiology, 44, 807-816.

Fitts, J.E. and Laird, D., 2004. Standart methods for the examination of dairy products: direct microscobic methods for bacteria of somatic cells (Chapter 10). Wehl, H. M., Frank, J. F., American Public Health Assoc.

Gleason J.M., Zhou, Y., Hackett, J.L., Haris, B.R. and Greenfield, M.D., 2016. Development of a genomic resource and quantitative trait loci mapping of male calling traits in the lesser wax moth, Achroia grisella. PLoS ONE 11(1): e0147014.

İzzetoğlu, S., Karaçali, S., 2003. The effects of 20hydroxyecdysone on hemocytes of Galleria mellonella (Lepidoptera) in vitro conditions. Gazi University. Journal of Science, 16, 233238.

Kazimírová, M. and Slovák, M., 1996. Effects of heavy metals and fluorine on phagocytosis and phenoloxidase activity in Mamestra brassicae (Lepidoptera: Noctuidae). European Journal of Entomology, 93, 467-473.

Kul, E., 2013. Jersey sığırlarında süt insülin benzeri büyüme faktörü-I (Igf-I) konsantrasyonu ile doğrusal puanlama özellikleri, süt somatik hücre sayısı ve verim özellikleri arasındaki ilişkiler, Doktora Tezi, Ondokuz Mayıs Üniversitesi, Fen Bilimleri Enstitüsü, Samsun.

Kurt, D., Kayış, T., 2015. Effects of the pyrethroid insecticide deltamethrin on the hemocytes of Galleria mellonella. Turkish Journal of Zoology, 39, 452-457.

Mahgoup, M.O, Lau, W.H. and Bin Omar, D., 2015. Observations on the biology and larval instars discrimination of wax moth Achroia grisella F. 
(Pyralidae: Lepidoptera). Journal of Entomology, 12(1), 1-11.

Prasada Rao, C.G., Ray, A. Ramamurty, P.S. 1984. Effect of ligation and ecdysone on total haemocyte count in the tobacco caterpillar, Spodoptera litura (Noctuidae: Lepidoptera). Canadian Journal of Zoology, 62, 1461-1463.

Sanjayan, K.P., Ravikumar, T. and Albert, S., 1996. Changes in the haemocyte profile of Spilostethus hospes (Fab) (Heteroptera: Lygaeidae) in relation to eclosion, sex and mating. Journal of Biosciences, 21(6), 781-788.

Sendi, J.J. and Salehi, R., 2010. The effect of methoprene on total hemocyte counts and histopathology of hemocytes in Papilio demoleus L. (Lepidoptera). Munis Entomology \& Zoology, 5(1), 240-246.

Sezer, B. and Özalp, P., 2015. Effects of pyriproxyfen on hemocyte count and morphology of Galleria mellonella. Fresenius Environmental Bulletin, 24(2a), 621-625.

Sharma, P.R., Sharma, O.P. and Saxena, B.P., 2003. Effect of neem gold on hemocytes of the tobacco armyworm, Spodoptera litura (Fabricius) (Lepidoptera: Noctuidae). Current Science, 84, 690-695.

Siddiqui, M.I. and Al-Khalifa, M.S., 2014. Review of haemocyte count, response to chemicals, phagocytosis, encapsulation and metamorphosis in insects. Italian Journal of Zoology, 81(1), 215 .

Suganya, M., Karthi, S. and Shivakumar, M.S., 2016. Effect of cadmium and lead exposure on tissue specific antioxidant response in Spodoptera litura. Free Radicals and Antioxidants, 6(1), 90100. 